\title{
Replacement of fishmeal for soy protein concentrate in diets for juvenile Litopenaeus vannamei in biofloc-based rearing system
}

\author{
Adolfo Jatobá ${ }^{*}$, Felipe do Nascimento Vieira², Bruno Corrêa da Silva ${ }^{3}$, Mariana Soares ${ }^{2}$, José \\ Luiz Pedreira Mouriño ${ }^{2}$, Walter Quadros Seiffert ${ }^{2}$
}

\footnotetext{
1 Instituto Federal de Educação, Ciência e Tecnologia Catarinense, Laboratório de Aquicultura, Araquari, SC, Brazil.

2 Universidade Federal de Santa Catarina, Departamento de Aquicultura, Laboratório de Camarões Marinho, Florianópolis, SC, Brazil.

${ }^{3}$ Empresa de Pesquisa Agropecuária e Extensão Rural de Santa Catarina, Centro de Desenvolvimento em Aquicultura e Pesca, Florianópolis, SC, Brazil.
}

ABSTRACT - This study aimed to assess the final body weight, weekly weight gain, yield, apparent feed efficiency, protein efficiency ratio, and feed intake of the Pacific white shrimp (Litopenaeus vannamei) fed four diets containing different levels of soy protein concentrate (SPC) as a replacement for fishmeal, reared in a super-intensive biofloc system. Diets consisted of replacing $209 \mathrm{~g} \mathrm{~kg}^{-1}$ fishmeal at $0,33,66$, and $100 \%$ SPC. Shrimp were raised in a biofloc system using twelve experimental units stocked with 250 shrimp $\mathrm{m}^{-3}$ under constant aeration $\left(\mathrm{O} 2>5 \mathrm{mg} \mathrm{L}^{-1}\right)$ and temperature $\left(29 \pm 0.5{ }^{\circ} \mathrm{C}\right)$. No significant differences among treatments were observed based on water quality parameters. Shrimp fed diets with 0 and $33 \%$ substitution exhibited the highest weekly growth (1.88 and $1.79 \mathrm{~g}$ per week) and final weights (15.2 and $14.7 \mathrm{~g})$ compared with shrimp fed the 66 and 100\% replacement. A lower feed intake was observed for shrimp fed the 33\% SPC diet (3.18 kg per experimental unit) compared with $0 \%$ replacement $(3.62 \mathrm{~kg}$ ). Shrimp fed the $33 \%$ replacement achieved a similar performance and lower feed intake than animals fed diet without replacement.

Key Words: aquaculture, intensive system, nutrition, protein sources

\section{Introduction}

The biofloc technology (BFT) system has become a promising alternative to promote the sustainability and biosecurity of shrimp culture by the utilisation of smaller volumes of water. Biofloc are aggregates of organic material and microorganisms, including bacteria, protozoa, and algae. As such, it is considered a supplementary food source for animals raised in this type of farming system (Avnimelech, 1999).

Marine shrimp feeds are still dependent on different degrees of fishmeal, due to its attractability and palatability proprieties and nutritional content, including amino acids and essential fatty acids, as well as vitamins and minerals (Amaya et al., 2007a,b; Suárez et al., 2009). However, a reduction or replacement of fishmeal for a suitable

Received: October 19, 2016

Accepted: July 13, 2017

*Corresponding author: jatobaadolfo@gmail.com

http://dx.doi.org/10.1590/S1806-92902017000900001

How to cite: Jatobá, A.; Vieira, F. N.: Silva, B. C.; Soares, M.; Mouriño, J. L. P. and Seiffert, W. Q. 2017. Replacement of fishmeal for soy protein concentrate in diets for juvenile Litopenaeus vannamei in biofloc-based rearing system. Revista Brasileira de Zootecnia 46(9):705-713.

Copyright (c) 2017 Sociedade Brasileira de Zootecnia. This is an Open Access article distributed under the terms of the Creative Commons Attribution License (http://creativecommons.org/licenses/by/4.0/), which permits unrestricted use, distribution, and reproduction in any medium, provided the original work is properly cited. alternative ingredient would be desirable, preferably one that is cheaper and renewable.

Previous nutritional studies have attempted to find a renewable substitute with a high concentration of protein, adequate amino acid profile, and lower cost relative to fishmeal (Hardy, 2010; Ray et al., 2010; Sookying et al., 2013). Among soy derivatives, soybean protein concentrate (SPC) appears most promising because it has a better amino acid profile and nutritional balance, greater digestibility (energetic and protein), low carbohydrate and fibre levels, and lower levels of anti-nutritional factors compared with other protein sources of vegetable origin (Suárez et al., 2009; Gamboa-Delgado et al., 2013). However, compared with fishmeal, SPC does have a methionine deficit (Drew et al., 2007).

Paripatananont et al. (2001) and Bauer et al. (2012) evaluated diets with 350 and $400 \mathrm{~g}$ fishmeal $/ \mathrm{kg}$ diet for Penaeus monodon and Litopenaeus vannamei, with 0, 25, 50,75 , and $100 \%$ of fishmeal replaced by SPC in clear water. Both studies indicated a significant potential for its use in the diet of marine shrimp. Although SPC has been considered a possible replacement for fishmeal, little information is available (Gatlin III et al., 2007; Sá et al., 2013) on its use in BFT for Pacific white shrimp. Therefore, the objective of this research was to evaluate the water quality, biofloc chemical composition, growth performance (survival, feed efficiency, protein efficiency ratio), and 
chemical composition of the Pacific white shrimp ( $L$. vannamei) reared in a super-intensive BFT system with diets containing different levels of SPC as a replacement for fishmeal.

\section{Material and Methods}

The study was conducted for 40 days between March and April 2013. The BFT system was implemented in Barra da Lagoa, Florianopolis ( $\left.27^{\circ} 58^{\prime} \mathrm{S}, 48^{\circ} 44^{\prime} \mathrm{W}\right), \mathrm{SC}$, Southern Brazil.

Four different isocaloric diets were formulated (Table 1) with different levels of SPC as a replacement for fishmeal $(0,33,66$, and 100\%). Diets were formulated with 300-330 $\mathrm{g} \mathrm{kg}^{-1}$ of crude protein (Jatobá et al., 2014) and similar amounts of marine-origin lipids (fish oil + fat contained in the fishmeal), aiming to provide similar fatty acid composition.

Diets were produced in Eusébio, CE, Brazil. The dry ingredients (fishmeal, soy protein concentrate, soybean, broken rice, and wheat flour) were first ground and sieved

Table 1 - Composition of the experimental diets for marine shrimp (L. vannamei) cultured in super-intensive BFT system with different replacement levels of fishmeal for soybean protein concentrate

\begin{tabular}{|c|c|c|c|c|}
\hline \multirow{2}{*}{ Ingredient $\left(\mathrm{g} \mathrm{kg}^{-1}\right)$} & \multicolumn{4}{|c|}{ Replacement level (\%) } \\
\hline & 0 & 33 & 66 & 100 \\
\hline Fishmeal $\left(590 \mathrm{~g} \mathrm{~kg}^{-1} \mathrm{CP}\right)^{1}$ & 209 & 132 & 60 & 0 \\
\hline Soy protein concentrate ${ }^{2}$ & 0 & 65 & 120 & 172 \\
\hline Soy meal $\left(450 \mathrm{~g} \mathrm{~kg}^{-1} \mathrm{CP}\right)$ & 350 & 350 & 350 & 350 \\
\hline Broken rice & 80 & 80 & 80 & 80 \\
\hline Wheat flour & 250 & 250 & 250 & 250 \\
\hline Soy lecithin & 15 & 15 & 15 & 15 \\
\hline Fish oil & 06 & 13 & 20 & 25 \\
\hline Soybean oil & 20 & 20 & 20 & 20 \\
\hline Potassium chloride & 15 & 14 & 10 & 09 \\
\hline Sodium chloride & 14 & 15 & 15 & 15 \\
\hline Magnesium sulfate & 08 & 08 & 08 & 08 \\
\hline Vitamin-C monophosphate & 03 & 03 & 03 & 03 \\
\hline Kaolin & 08 & 13 & 27 & 31 \\
\hline Phosphate monodicalcium phoscalcium 20 & 07 & 07 & 07 & 07 \\
\hline Premix $^{3}$ & 15 & 15 & 15 & 15 \\
\hline
\end{tabular}

BFT - biofloc technology; CP - crude protein.

${ }^{1}$ Nicoluzzi Rações Ltda. (Penha, SC, Brazil).

${ }^{2}$ IMCOPA - Importação, Exportação e Indústria de Óleos S.A. (Araucária, PR, Brazil) proximate composition: $630.7 \mathrm{~g} \mathrm{~kg}^{-1}$ crude protein; $13.8 \mathrm{~g} \mathrm{~kg}^{-1}$ crude lipid; $46.6 \mathrm{~g} \mathrm{~kg}^{-1}$ crude fiber; $67.9 \mathrm{~g} \mathrm{~kg}^{-1}$ moisture; $63.2 \mathrm{~g} \mathrm{~kg}^{-1}$ ash; $177.8 \mathrm{~g} \mathrm{~kg}^{-1}$ non-nitrogen extract; $13.8 \mathrm{~g} \mathrm{~kg}^{-1}$ extract by acid hydrolysis; $4,426.0 \mathrm{cal} \mathrm{g}{ }^{-1}$; amino acid profile: aspartic acid, $6.67 \mathrm{~g} \mathrm{~kg}^{-1}$; glutamic acid, $100.3 \mathrm{~g} \mathrm{~kg}^{-1}$; serine, $26.5 \mathrm{~g} \mathrm{~kg}^{-1}$; glycine, $19.0 \mathrm{~g} \mathrm{~kg}^{-1}$; histidine, $16.8 \mathrm{~g} \mathrm{~kg}^{-1}$; arginine, $36.9 \mathrm{~g} \mathrm{~kg}^{-1}$; threonine, $17.4 \mathrm{~g} \mathrm{~kg}^{-1}$; proline, $27.3 \mathrm{~g} \mathrm{~kg}^{-1}$; tyrosine, $16.9 \mathrm{~g} \mathrm{~kg}^{-1}$; valine, $27.3 \mathrm{~g} \mathrm{~kg}^{-1}$; methionine, $7.1 \mathrm{~g} \mathrm{~kg}^{-1}$; methionine + cystine, $13.7 \mathrm{~g} \mathrm{~kg}^{-1}$; isoleucine, $28.2 \mathrm{~g} \mathrm{~kg}^{-1}$; leucine, $49.9 \mathrm{~g} \mathrm{~kg}^{-1}$; phenylalanine, $30.4 \mathrm{~g} \mathrm{~kg}^{-1}$; and lysine $39.2 \mathrm{~g} \mathrm{~kg}^{-1}$.

${ }^{3}$ Guaranteed levels per kg: vitamin A, 1,250,000 IU; vitamin D3, 350,000 IU; vitamin E, 25,000 IU; vitamin $\mathrm{K} 3,500 \mathrm{mg}$; vitamin B1, 5,000 mg; vitamin B2, 4,000 mg; vitamin B6, $10 \mathrm{mg}$; nicotinic acid, $15,000 \mathrm{mg}$; pantothenic acid, 10,000 mg; biotin, $150 \mathrm{mg}$; folic acid, 1,250 mg; vitamin C, 25,000 mg; choline, 50,000 mg; inositol, 20,000 mg; iron 2,000 mg; copper, 3,500 mg; copper chelate, 15,000 mg; zinc, $10,500 \mathrm{mg}$; zinc chelate, 4,500 mg; manganese, 4,000 mg; selenic acid, $15 \mathrm{mg}$; selenium chelate, $15 \mathrm{mg}$; iodine, $150 \mathrm{mg}$; cobalt, $30 \mathrm{mg}$.
(500 $\mu \mathrm{m}$ mesh). After that, the microingredients were homogenised in a Y mixer for $10 \mathrm{~min}$ and then combined with the macroingredients for mixing in a food mixer for an additional $10 \mathrm{~min}$. Soon after, fish oil, soybean oil, and soy lecithin were added, followed by $20 \%$ water. The resulting mixture was extruded at $90{ }^{\circ} \mathrm{C}$ in a micro-extruder with a capacity of $15 \mathrm{~kg} \mathrm{~h}^{-1}$ (model EX Micro, EXTEEC Machines, São Paulo, Brazil) and dried to approximately $10 \%$ moisture in a drying oven $\left(35^{\circ} \mathrm{C}\right)$.

Shrimp used in this study were provided by Genearch Ltda. (Rio Grande do Norte, Brazil) and obtained from the breeding of a specific pathogen-free strain of mandatory notification (WSSV, IHHNV, TSV, IMNV, and YHV) as required by the Organization International des Epizooties (OIE). Shrimp were reared in a closed, intensive system with bioflocs until they reached the required body weight to begin the experiment.

Marine shrimp were grown under a super-intensive BFT system in a circular fibreglass tank with a capacity of $50 \mathrm{~m}^{3}$. Shrimp were sampled from three different locations in the tank and a total of 2,400 shrimp weighing $3.96 \pm 0.04 \mathrm{~g}$ (average \pm standard deviation) were transferred to the experimental units.

Shrimp were maintained under constant aeration at a temperature of approximately $27^{\circ} \mathrm{C}$. On the day juveniles were transferred, the water in the rearing tanks measured $35 \mathrm{~g} \mathrm{~L}^{-1}$ salinity, $27{ }^{\circ} \mathrm{C}$ temperature, $5.2 \mathrm{mg} \mathrm{L}^{-1}$ dissolved oxygen, $434 \mathrm{mg} \mathrm{L}^{-1}$ total suspended solids, $152 \mathrm{mg} \mathrm{L}^{-1}$ alkalinity, $0.27 \mathrm{mg} \mathrm{L}^{-1}$ ammonia, $3.06 \mathrm{mg} \mathrm{L}^{-1}$ nitrite, and $7.42 \mathrm{pH}$. The biofloc in the tank formed after 30 days. Biofloc were in a heterotrophic stage, thus molasses was added at a rate of $50 \%$ of the feed amount.

Until transfer to the experimental units, shrimp were fed four times a day with a commercial diet containing $350 \mathrm{~g} \mathrm{~kg}^{-1}$ crude protein (CP) (Guabi Vannamei $35 \mathrm{EXT}$, minimum of $350 \mathrm{~g} \mathrm{~kg}^{-1} \mathrm{CP}$; minimum of $75 \mathrm{~g} \mathrm{~kg}^{-1}$ ether extract; maximum of $100 \mathrm{~g} \mathrm{~kg}^{-1}$ humidity; maximum of $50 \mathrm{~g} \mathrm{~kg}^{-1}$ crude fibre; maximum of $130 \mathrm{~g} \mathrm{~kg}^{-1}$ mineral material; 15 to $30 \mathrm{~g} \mathrm{~kg}^{-1}$ calcium (Ca); minimum of $14.5 \mathrm{~g} \mathrm{~kg}^{-1}$ phosphorus (P); maximum of $3 \mathrm{~g} \mathrm{~kg}^{-1}$ magnesium $(\mathrm{Mg})$; and minimum of $8 \mathrm{mg} \mathrm{kg}^{-1}$ potassium $(\mathrm{K})$, according to the manufacturer).

Twelve experimental units of polyethylene with $800 \mathrm{~L}$ of water $\left(\right.$ radius $=0.65 \mathrm{~m}$, bottom area $=1.32 \mathrm{~m}^{2}$, depth $=0.60 \mathrm{~m}$ ) were independently supplied by pumping water from the biofloc culture system matrix tank. The units, which had an area of $4 \mathrm{~m}^{2}$ (bottom and sides), were extended by another $2 \mathrm{~m}^{2}$ by the addition of an artificial substrate (five rectangular substrates, $0.60 \times 0.65 \mathrm{~m}$ ) to comfortably accommodate the animals (Schveitzer et al., 2013a). Constant aeration was 
provided through diffusion hoses connected to a 7.5 -hp blower and titanium heaters $(800 \mathrm{~W})$ with a thermostat were used in each tank to maintain the temperature at $29 \pm 0.5^{\circ} \mathrm{C}$.

The experimental units were distributed among four treatments $(0,33,66$, and $100 \%$ of fishmeal replacement for SPC) completely at random, in triplicate. In each tank, 200 shrimps were stocked, maintaining an initial density of 250 shrimp $\mathrm{m}^{-3}$.

Shrimp were fed four times a day $(8: 00,11: 00,14: 00$, and 17:00 h) with a monitoring program to confirm intake, as described by Jatobá et al. (2014). The first feeding supplied $4 \%$ of the initial stocked shrimp biomass, with total $90 \%$ of the meal broadcast over the water surface and the remainder in feeding trays. After $1 \mathrm{~h}$, trays were checked to estimate the diet intake rate per experimental unit. When feed leftovers were observed after two consecutive feeding times, the amount of feed offered was reduced by $10 \%$. When no feed leftovers were observed after two consecutive feeding times, the amount of feed offered was increased by $10 \%$.

During the experiment, dissolved oxygen and temperature were measured two times a day. Measurements of $\mathrm{pH}$, floc volume (Imhoff cone), total dissolved ammonia, nitrites and nitrates, alkalinity, total suspended solids (APHA, 2005), dissolved orthophosphates (Strickland and Parsons, 1972), and salinity (refractometer) were performed twice a week.

The amount of solids was maintained approximately between 400 and $600 \mathrm{mg} \mathrm{L}^{-1}$ (Schveitzer et al., 2013b). When this value was exceeded, the excess was removed with the aid of sedimentation tanks with a capacity of $60 \mathrm{~L}$ (adapted from Ray et al., 2010).

Since the culture system was not equipped with a water exchange system, only the evaporated volume was replaced by fresh water. Calcium hydroxide was added when alkalinity fell below $120 \mathrm{mg} \mathrm{L}^{-1} \mathrm{CaCO}_{3}$ and, when necessary, the dose was $10 \%$ of the daily ration. Molasses was used until the 29th day of the experiment to estimated carbon:nitrogen ratio in the water between 12:1 and 15:1, in accordance with Avnimelech (1999).

Samples were collected weekly to quantify shrimp growth. At the end of the experiment, the apparent feed efficiency, protein efficiency ratio, apparent feed intake, specific growth rate, final body weight, weight gain, survival, and yield were assessed.

Samples of all diets were sent to Santa Maria, RS, Brazil, for analysis. Twelve shrimp samples and 12 biofloc samples were sent to Campinas, SP, Brazil, to determine the amino acid profile through high-performance liquid chromatography.
All amino acids were measured using AOAC (2005) official method 994.12, except methionine and cystine that were measured using AOAC (2005) official method 985.28. Protein contents were also measured according to AOAC (2005) using the Dumas nitrogen combustion method. Crude lipids were quantified using the ether extraction method and energy was determined with a bomb calorimeter. Crude fibre, ash, and moisture were determined using AOAC (2005) official methods 978.10, 942.05, and 930.15, respectively. Cholesterol concentration was also analyzed in the shrimp samples and amino acid profile was determined through HPLC in the biofloc samples.

All data were first subjected to Bartlett's analysis to verify the homogeneity of variance and then subjected to one-way ANOVA. Significant differences among treatments were analysed using the Student-NewmanKeuls test (SNK). All tests were conducted at a 5\% level of significance (Zar, 2010).

\section{Results}

The diets had similar proximate composition. The most divergent essential amino acid values were observed in phenylalanine, lysine, methionine, methionine + cystine, glutamic acid and glycine (Table 2).

Shrimp fed the $0 \%$ and $33 \%$ replacement levels showed higher average final weight and weekly gain than those fed the 66 and $100 \%$ replacement. The yield and intake were higher in the treatment without replacement than with $100 \%$. Survival, apparent feed efficiency, and protein efficiency ratio did not vary among treatments (Table 3).

Biofloc proximate composition showed more ash, arginine, methionine, alanine, proline, and glycine in treatment without fishmeal replacement than with $100 \%$. Aspartic acid was lower in treatment with 33\% replacement than with $100 \%$. Other amino acid and proximate composition of biofloc (Table 4), as well as the variables of water quality (Table 5) and proximate composition of dried marine shrimp (Table 6) did not vary among treatments.

\section{Discussion}

Experimental diets in this work showed proximate composition and amino acid profiles, with small differences among dietary treatments. Some amino acids such as arginine, phenylalanine, isoleucine, leucine, and glutamic acid increased their concentrations in diets with higher fishmeal replacement, while ash, histidine, methionine, methionine + cystine, and glycine reduced with the increase of fish meal replacement for SPC. No trend was 
observed for crude fibre, lysine, threonine, valine, alanine, aspartic acid; these nutrients did not vary according to the replacement levels; in addition, valine, proline, and serine maintained close concentrations, regardless of replacement levels of SPC for fishmeal (Table 2). These fluctuations in dietary amino acid concentration are normal when trying

Table 2 - Proximate composition and amino acid prolife of the experimental diets for marine shrimp (L. vannamei) cultured in BFT system with different levels of replacement of fishmeal for soybean protein concentrate

\begin{tabular}{|c|c|c|c|c|}
\hline & \multicolumn{4}{|c|}{ Replacement (\%) } \\
\hline & 0 & 33 & 66 & 100 \\
\hline \multicolumn{5}{|c|}{ Chemical composition $\left(\mathrm{g} \mathrm{kg}^{-1}\right)$} \\
\hline Crude protein & 334.0 & 327.0 & 322.0 & 319.0 \\
\hline Crude lipid & 63.0 & 66.0 & 61.0 & 66.0 \\
\hline Nitrogen-free extract & 351.0 & 369.0 & 380.0 & 390.0 \\
\hline Ash & 127.0 & 121.0 & 114.0 & 104.0 \\
\hline Crude fiber & 22.0 & 24.0 & 22.0 & 27.0 \\
\hline Moisture & 104.0 & 93.0 & 102.0 & 99.0 \\
\hline Gross energy ( $\mathrm{kcal} \mathrm{kg}^{-1}$ ) & $3,909.0$ & $3,973.0$ & $3,903.0$ & $4,002.0$ \\
\hline \multicolumn{5}{|c|}{ Amino acid profile $\left(\mathrm{g} \mathrm{kg}^{-1}\right)$} \\
\hline \multicolumn{5}{|l|}{ Essential amino acid } \\
\hline Arginine & 16.2 & 16.4 & 16.9 & 17.1 \\
\hline Phenylalanine & 13.1 & 14.3 & 14.2 & 15.0 \\
\hline Histidine & 7.2 & 6.9 & 6.7 & 5.8 \\
\hline Isoleucine & 13.1 & 13.7 & 13.5 & 13.8 \\
\hline Leucine & 21.8 & 22.5 & 22.3 & 22.8 \\
\hline Lysine & 21.9 & 28.1 & 24.7 & 24.8 \\
\hline Methionine & 9.4 & 8.1 & 7.2 & 6.3 \\
\hline Methionine + cystine & 13.7 & 12.4 & 11.5 & 10.5 \\
\hline Threonine & 7.8 & 6.9 & 7.8 & 7.3 \\
\hline Valine & 13.6 & 14.2 & 13.9 & 13.7 \\
\hline \multicolumn{5}{|l|}{ Nonessential amino acid } \\
\hline Alanine & 12.5 & 11.3 & 11.6 & 11.2 \\
\hline Aspartic acid & 27.1 & 26.8 & 28.8 & 27.8 \\
\hline Glutamic acid & 45.2 & 46.6 & 48.5 & 50.3 \\
\hline Glycine & 11.8 & 10.3 & 9.8 & 9.2 \\
\hline Proline & 14.3 & 14.2 & 14.3 & 14.3 \\
\hline Serine & 11.2 & 11.0 & 11.5 & 11.3 \\
\hline Tyrosine & 7.3 & 7.3 & 7.2 & 7.7 \\
\hline
\end{tabular}

BFT - biofloc technology.

Data from a sample of each diet. to perform a replacement of some ingredient (Kuhn et al., 2016; Xie et al., 2016).

Methionine concentrations, at $100 \%$ replacement level, were below the recommended 7.0-9.0 $\mathrm{g} \mathrm{kg}^{-1}$ (NRC, 2011). However, the sum of methionine + cystine may have compensated for these levels, because $50 \%$ of the requirement for methionine can be provided by this combination, thus justifying the growth performance obtained in this research (Lall and Dumas, 2015). In addition, in all diets, arginine and histidine concentrations were below the recommended 19.0 and $8.0 \mathrm{~g} \mathrm{~kg}^{-1}$, respectively (NRC, 2011). Even though these values were below recommendation levels, the results might still be considered promising based on shrimp growth performance (Table 3). It is likely that the requirements for these amino acids were partially met by their availability in the bioflocs, which provided some of the nutrients (Table 4) that were otherwise below recommended levels. However, even the presence of bioflocs was insufficient to promote equitable growth performance among treatments.

Water quality parameters were similar among treatments and recorded small variations in some parameters such as $\mathrm{pH}$ and suspended solids, demonstrating that the system was stable (Table 5), remaining within the recommended limits for white shrimp culture. These results corroborated the results of Bauer et al. (2012) and Sá et al. (2013), who did not observe any significant differences in water quality parameters using fishmeal or SPC as protein source in clear water.

The replacement of fishmeal in the diets of marine shrimp has been proposed by many authors. However there are many contradictory results (Amaya et al., 2007a,b; Suárez et al., 2009; Tacon and Metian, 2008; Bauer et al., 2012; Gamboa-Delgado et al., 2013; Sá et al., 2013; Sookying et al., 2013; Yang et al., 2015; Carvalho et al., 2016; Kuhn et al., 2016; Xie et al., 2016). Ray et al. (2010) demonstrated the potential of soybean products for replacing fishmeal after culturing 460 shrimp $\mathrm{m}^{-3}$ in a BFT. In the present study,

Table 3 - Growth performance (mean \pm SD), during 40 days, of marine shrimp (L. vannamei) cultured in BFT system and fed diets containing different replacement levels of fishmeal for soybean protein concentrate

\begin{tabular}{|c|c|c|c|c|}
\hline \multirow{2}{*}{ Animal performance index } & \multicolumn{4}{|c|}{ Replacement level (\%) } \\
\hline & 0 & 33 & 66 & 100 \\
\hline Initial weight (g) & $3.95 \pm 0.04$ & $3.97 \pm 0.01$ & $3.97 \pm 0.03$ & $3.96 \pm 0.03$ \\
\hline Final weight (g) & $15.20 \pm 0.55 \mathrm{a}$ & $14.70 \pm 0.46 \mathrm{a}$ & $13.53 \pm 0.52 b$ & $13.39 \pm 0.27 b$ \\
\hline Weekly gain $\left(\mathrm{g} \mathrm{week}^{-1}\right)$ & $1.88 \pm 0.09 \mathrm{a}$ & $1.79 \pm 0.08 \mathrm{a}$ & $1.59 \pm 0.08 b$ & $1.57 \pm 0.04 b$ \\
\hline Yield $\left(\mathrm{kg} \mathrm{m}^{-3}\right)$ & $3.16 \pm 0.15 \mathrm{a}$ & $2.83 \pm 0.19 \mathrm{ab}$ & $2.79 \pm 0.16 \mathrm{ab}$ & $2.56 \pm 0.18 b$ \\
\hline Survival (\%) & $83.08 \pm 3.59$ & $77.09 \pm 4.36$ & $82.39 \pm 3.00$ & $80.13 \pm 9.11$ \\
\hline AFE & $0.48 \pm 0.03$ & $0.47 \pm 0.04$ & $0.46 \pm 0.05$ & $0.49 \pm 0.08$ \\
\hline PER & $1.45 \pm 0.09$ & $1.44 \pm 0.14$ & $1.44 \pm 0.15$ & $1.54 \pm 0.25$ \\
\hline Consumption (kg) & $3.62 \pm 0.11 \mathrm{a}$ & $3.18 \pm 0.03 b$ & $3.18 \pm 0.46 \mathrm{~b}$ & $2.79 \pm 0.08 \mathrm{c}$ \\
\hline
\end{tabular}

SD - standard deviation; BFT - biofloc technology; AFE - apparent feed efficiency; PER - protein efficiency ratio.

Different letters indicate significant differences $(\mathrm{P}<0.05)$ between treatments using one-way ANOVA and SNK for mean separation. 
shrimp fed diets containing 0 and $33 \%$ replacement of fishmeal for SPC had higher final body weights and weekly gains compared with shrimp fed diets having either 66 or $100 \%$ replacement (Table 2). This could be attributed to lower levels of essential nutrients (below recommendation) or unknown growth factor of fishmeal (Hardy, 2010; Ray et al., 2010; Sookying et al., 2013). These essential nutrients could include methionine, threonine, or histidine in the higher percentage replacement diets. For this reason, Gatlin III et al. (2007) suggested supplementation of

Table 4 - Biofloc chemical composition and amino acid prolife in tanks with marine shrimp (L. vannamei) cultured during 40 days in a BFT system and fed diets containing different replacement levels of fishmeal for soy protein concentrate

\begin{tabular}{|c|c|c|c|c|}
\hline & \multicolumn{4}{|c|}{ Replacement level (\%) } \\
\hline & 0 & 33 & 66 & 100 \\
\hline \multicolumn{5}{|c|}{ Centesimal composition $\left(\mathrm{g} \mathrm{kg}^{-1}\right)$} \\
\hline Crude lipid & $23.0 \pm 3.0$ & $22.0 \pm 7.0$ & $20.0 \pm 3.0$ & $20.0 \pm 1.0$ \\
\hline Nitrogen-free extract & $69.0 \pm 34.0$ & $92.0 \pm 71.0$ & $87.0 \pm 66.0$ & $74.0 \pm 65.0$ \\
\hline Ash & $510.0 \pm 4.0 \mathrm{~b}$ & $503.0 \pm 16.0 \mathrm{ab}$ & $482.0 \pm 13.0 \mathrm{ab}$ & $473.0 \pm 0.09 \mathrm{a}$ \\
\hline Crude fiber & $120.0 \pm 39.0$ & $117.0 \pm 58.0$ & $128.0 \pm 65.0$ & $170.0 \pm 66.0$ \\
\hline \multicolumn{5}{|c|}{ Amino acid profile $\left(\mathrm{g} \mathrm{kg}^{-1}\right)$} \\
\hline \multicolumn{5}{|l|}{ Essential amino acid } \\
\hline Arginine & $13.8 \pm 0.2 b$ & $12.5 \pm 1.0 \mathrm{ab}$ & $13.3 \pm 0.2 b$ & $11.5 \pm 0.6 \mathrm{a}$ \\
\hline Phenylalanine & $10.1 \pm 0.5$ & $9.5 \pm 1.0$ & $10.1 \pm 0.3$ & $9.5 \pm 0.4$ \\
\hline Histidine & $4.6 \pm 0.2$ & $4.2 \pm 0.4$ & $4.7 \pm 0.2$ & $4.3 \pm 0.4$ \\
\hline Isoleucine & $8.8 \pm 0.8$ & $8.1 \pm 1.6$ & $8.8 \pm 0.4$ & $8.4 \pm 0.3$ \\
\hline Tryptophan & $1.4 \pm 0.4$ & $1.4 \pm 0.5$ & $1.8 \pm 0.1$ & $1.6 \pm 0.3$ \\
\hline Valine & $13.2 \pm 1.1$ & $12.5 \pm 1.8$ & $13.2 \pm 0.5$ & $12.4 \pm 0.5$ \\
\hline \multicolumn{5}{|l|}{ Nonessential amino acid } \\
\hline Alanine & $17.3 \pm 0.8 \mathrm{~b}$ & $16.0 \pm 1.4 \mathrm{ab}$ & $16.7 \pm 0.3 \mathrm{ab}$ & $14.9 \pm 0.8 \mathrm{a}$ \\
\hline Aspartic acid & $6.4 \pm 0.6 \mathrm{ab}$ & $5.6 \pm 0.9 \mathrm{a}$ & $6.7 \pm 0.4 \mathrm{ab}$ & $8.4 \pm 1.4 \mathrm{~b}$ \\
\hline Cystine & $4.2 \pm 0.1$ & $4.2 \pm 0.4$ & $4.3 \pm 0.1$ & $4.5 \pm 0.5$ \\
\hline Glutamic acid & $17.3 \pm 1.2$ & $18.1 \pm 3.0$ & $18.9 \pm 1.0$ & $19.4 \pm 2.7$ \\
\hline Glycine & $18.5 \pm 0.2 \mathrm{a}$ & $16.5 \pm 0.6 \mathrm{~b}$ & $17.0 \pm 0.2 \mathrm{~b}$ & $15.8 \pm 0.4 \mathrm{c}$ \\
\hline Proline & $11.0 \pm 0.1 \mathrm{~b}$ & $10.3 \pm 0.3 b$ & $10.4 \pm 0.3 b$ & $8.8 \pm 0.5 \mathrm{a}$ \\
\hline Serine & $10.9 \pm 0.2$ & $10.1 \pm 0.7$ & $11.1 \pm 0.2$ & $10.7 \pm 0.5$ \\
\hline Tyrosine & $8.8 \pm 0.3$ & $8.5 \pm 1.0$ & $9.2 \pm 0.2$ & $8.6 \pm 0.3$ \\
\hline
\end{tabular}

BFT - biofloc technology.

Different letters indicate significant differences $(\mathrm{P}<0.05)$ between treatments using one-way ANOVA and SNK for mean separation.

Table 5 - Water quality results (mean $\pm \mathrm{SD}$ ) of marine shrimp (L. vannamei) cultured during 40 days in BFT system and fed diets containing different replacement levels of fishmeal for soybean protein concentrate

\begin{tabular}{|c|c|c|c|c|}
\hline \multirow{2}{*}{ Water quality parameter } & \multicolumn{4}{|c|}{ Replacement level (\%) } \\
\hline & 0 & 33 & 66 & 100 \\
\hline Dissolved oxygen $\left(\mathrm{mg} \mathrm{L}^{-1}\right)$ & $5.6 \pm 0.2$ & $5.5 \pm 0.2$ & $5.3 \pm 0.1$ & $5.5 \pm 0.2$ \\
\hline Temperature $\left({ }^{\circ} \mathrm{C}\right)$ & $29.0 \pm 0.2$ & $29.0 \pm 0.1$ & $29.0 \pm 0.3$ & $29.0 \pm 0.4$ \\
\hline Salinity (\%o) & $37.9 \pm 0.1$ & $37.9 \pm 0.1$ & $38.0 \pm 0.1$ & $38.0 \pm 0.1$ \\
\hline Turbidity $(\mathrm{cm})$ & $8.4 \pm 3.1$ & $8.5 \pm 0.0$ & $8.3 \pm 1.0$ & $7.5 \pm 0.7$ \\
\hline Suspended solids (mL L $\left.{ }^{-1}\right)$ & $15.5 \pm 0.1$ & $15.3 \pm 1.1$ & $14.5 \pm 0.1$ & $14.4 \pm 0.9$ \\
\hline Total suspended solids $\left(\mathrm{mg} \mathrm{L}^{-1}\right)$ & $585.2 \pm 16.1$ & $579.3 \pm 8.6$ & $558.7 \pm 12.6$ & $554.4 \pm 14.0$ \\
\hline Fixed solids $(\%)$ & $56.9 \pm 1.1$ & $56.8 \pm 0.6$ & $57.0 \pm 1.2$ & $56.3 \pm 1.2$ \\
\hline Volatile suspended solids (\%) & $43.1 \pm 1.1$ & $43.2 \pm 0.6$ & $43.0 \pm 1.2$ & $43.7 \pm 1.2$ \\
\hline $\mathrm{pH}$ & $7.6 \pm 0.2$ & $7.6 \pm 0.2$ & $7.6 \pm 0.2$ & $7.6 \pm 0.2$ \\
\hline Ammonia (mg L $\left.{ }^{-1}\right)$ & $0.2 \pm 0.1$ & $0.2 \pm 0.1$ & $0.2 \pm 0.1$ & $0.2 \pm 0.1$ \\
\hline Nitrite $\left(\mathrm{mg} \mathrm{L}^{-1}\right)$ & $3.1 \pm 0.1$ & $3.0 \pm 0.1$ & $3.1 \pm 0.1$ & $3.0 \pm 0.1$ \\
\hline Nitrate $\left(\mathrm{mg} \mathrm{L}^{-1}\right)$ & $41.3 \pm 21.9$ & $43.0 \pm 23.8$ & $44.8 \pm 27.9$ & $40.4 \pm 23.4$ \\
\hline Alkalinity (mg L $\left.{ }^{-1}\right)$ & $142.6 \pm 38.0$ & $136.6 \pm 27.4$ & $138.6 \pm 38.0$ & $135.5 \pm 28.1$ \\
\hline Phosphate $\left(\mathrm{mg} \mathrm{L}^{-1}\right)$ & $11.4 \pm 1.6$ & $11.1 \pm 1.6$ & $12.6 \pm 2.1$ & $11.8 \pm 2.0$ \\
\hline
\end{tabular}

SD - standard deviation; BFT - biofloc technology. 
Table 6 - Cholesterol and chemical composition of dried marine shrimp (L. vannamei) cultured during 40 days in BFT system and fed diets containing different replacement levels of fishmeal for soybean protein concentrate

\begin{tabular}{lcccc}
\hline \multirow{2}{*}{ Proximate composition $\left(\mathrm{g} \mathrm{kg}^{-1}\right)$} & \multicolumn{4}{c}{ Replacement level (\%) } \\
\cline { 2 - 5 } & 0 & 33 & 66 & 100 \\
\hline Cholesterol & $6.0 \pm 1.0$ & $6.0 \pm 0.0$ & $6.0 \pm 1.0$ & $6.0 \pm 10.0$ \\
Crude protein & $892.0 \pm 42.0$ & $963.0 \pm 73.4$ & $853.0 \pm 97.0$ & $887.0 \pm 136.0$ \\
Crude fat & $58.0 \pm 10.0$ & $63.0 \pm 7.0$ & $67.0 \pm 17.0$ & $65.0 \pm 6.0$ \\
Ash & $119.0 \pm 13.0$ & $108.0 \pm 11.0$ & $107.0 \pm 3.0$ & $107.0 \pm 12.0$ \\
Crude fiber & $59.0 \pm 6.0$ & $58.0 \pm 6.0$ & $55.0 \pm 9.0$ & $61.0 \pm 5.0$ \\
Phosphorus & $11.0 \pm 2.0$ & $10.0 \pm 1.0$ & $10.0 \pm 2.0$ & $10.0 \pm 0.0$ \\
Gross energy $\left(\mathrm{kcal} \mathrm{kg}^{-1}\right)$ & $3,980.3 \pm 57.7$ & $4,013.0 \pm 47.1$ & $3,899.0 \pm 88.3$ & $3,917.0 \pm 93.0$ \\
\hline
\end{tabular}

BFT - biofloc technology.

methionine and threonine in diets with higher levels of replacement of fishmeal for SPC. Even without inclusion of synthetic amino acids or any other feed additives, in this study, 33\% fishmeal replacement in a diet containing 33\% crude protein was feasible to be used for shrimp culture under BFT.

Shrimp final was adequate for the species, with an average of over $77.0 \%$ (Table 3). The weekly gain was similar to that observed by Jatobá et al. (2014) for shrimp fed experimental diets containing fishmeal (1.79 g/week). For shrimp fed a diet with $100 \%$ replacement of fishmeal, the lowest weekly gain of $1.57 \mathrm{~g}$ was still higher than the growth reported in other studies with fishmeal-free diets (Ray et al., 2010; Scopel et al., 2011; Sookying and Davis, 2011; Bauer et al., 2012; Sá et al., 2013) or experimental and/or commercial diets with fishmeal (Ray et al., 2010; Scopel et al., 2011; Bauer et al., 2012; Sá et al., 2013; Schveitzer et al., 2013a; 2013b). These results demonstrated that the diet without fishmeal, even though deficient in essential amino acids, provided a satisfactory growth. However, to improve these results, it would be necessary to assess different diets, carbon sources, or any other inputs that enhance the nutritional value of the biofloc (Avnimelech, 2006; Michaud et al., 2006; Wasielesky et al., 2006; Ray et al., 2010).

White shrimp fed a diet with $100 \%$ replacement of fishmeal for SPC weighed an average of $13.84 \mathrm{~g}, 0.50 \mathrm{~g}$ lower than shrimp fed diets without fishmeal replacement, after ten weeks of culture in clear water (Sá et al., 2013). The same authors tested $31 \%$ fishmeal replacement for SPC with the inclusion of $20 \mathrm{~g}$ of fish oil per $\mathrm{kg}$ of feed. These data corroborated our results, indicating that replacement of $33 \%$ of the fishmeal in the diet with SPC, including $25.1 \mathrm{~g}$ of marine lipids added per $\mathrm{kg}$ feed, did not harm shrimp performance.

Apparent feed efficiency and protein efficiency ratio showed similar efficiency in $100 \%$ replacement (Table 3), which could be explained by a similar apparent crude protein digestibility in diets with different levels of fishmeal or SPC inclusion (Carvalho et al., 2016). This corroborates other studies with L. vannamei, in which SPC was used as the main protein source in the diet (Bauer et al., 2012; Sookying and Davis, 2011; Sá et al., 2013). A higher yield and apparent feed intake were observed in shrimp fed the diet without replacement ( $0 \%$ ) compared with $100 \%$ replacement (Table 3).

Several factors may affect shrimp feed intake, including water quality (temperature, dissolved oxygen, and nitrogen compounds), diet composition, energy, and feed attractiveness and palatability (Kureshy and Davis, 2002; Cuzon et al., 2004; Nunes et al., 2006). All treatments resulted in the same apparent feed efficiency, suggesting a similar feed conversion in the tissues of animals. Therefore, the low final weight and weekly gain of shrimp fed a diet with $100 \%$ replacement of fishmeal may have resulted from lower food intake because high concentrations of plant ingredients reduce attractiveness and palatability (Nunes et al., 2006; Amaya et al., 2007a,b).

Bioflocs provide a constant source of food for farmed animals (Avnimelech, 1999; Burford et al., 2003; Avnimelech, 2006; Michaud et al., 2006; Wasielesky et al., 2006; Taw, 2010; Jatobá et al., 2014). In the proximate composition of bioflocs, a higher level of ash was observed in the tanks with shrimp fed diet without replacement of fishmeal $(0 \%)$ in comparison with tanks with $100 \%$ replacement, whereas the 33 and $66 \%$ treatments were not significantly different. This result can be attributed to the higher concentration of ash in fishmeal compared with SPC. For crude protein, ether extract, nitrogen extract, crude fibre, or energy, no significant differences were seen among the dietary treatments (Table 5).

A higher concentration of alanine was observed in the biofloc of tanks without fishmeal replacement $(0 \%)$ compared with tanks with $100 \%$ replacement. Treatments with 33 and $66 \%$ replacement did not differ from others. Higher concentrations of fibre, arginine, and methionine were detected in the biofloc of treatments with 0 and 
$66 \%$ replacement relative to arginine and methionine concentrations with $100 \%$ replacement. Aspartic acid concentration was higher in the bioflocs of tanks with shrimp fed $100 \%$ replacement compared with that in the bioflocs of tanks with shrimp fed $33 \%$ replacement. Finally, proline concentration was lower for treatment with $100 \%$ replacement compared with other treatments. No other amino acids showed significant differences among dietary treatments (Table 5).

Bioflocs can be used as food source containing potential "growth promoters" (Avnimelech, 1999, 2006; Burford et al., 2003; Michaud et al., 2006; Taw, 2010; Wasielesky et al., 2006). In this study, different trends were recorded between diet and biofloc compositions. For example, methionine, glycine, and alanine were decreased in high levels of replacement, probably because SPC contains lower level of these amino acids than fishmeal. Only arginine was higher in the diet with $100 \%$ fishmeal replacement, though its concentration was lower in the biofloc of the same treatment. These results showed no correlation between diets and biofloc proximate composition. However each nutrient may have a different fluctuation and these differences did not affect the survival or apparent feed efficiency of the shrimp or their composition. This can suggest that diets and biofloc contain sufficient nutrients for shrimp performance, probably because of a growth-promoting effect, which may be associated with trace minerals or other unknown nutrients (Sabry Neto et al., 2015).

It is well known that the nutritional value of bioflocs can be influenced by the developmental stage of microbial biofloc, whether autotrophic, heterotrophic, or chemoautotrophic, as well as the adopted management plan. Also, the heterotrophic phase provides more nutritional value (Avnimelech, 2006; Ebeling et al., 2006; Wasielesky et al., 2006; Taw, 2010) than the others. The levels of crude protein in the biofloc $\left(275.9 \mathrm{~g} \mathrm{~kg}^{-1}\right)$ were higher than those (average $194.7 \mathrm{~g} \mathrm{~kg}^{-1}$ ) observed by other authors (Chamberlain et al., 2001; Tacon et al., 2002; Williams et al., 2005; Wasielesky et al., 2006; Taw, 2010; Jatobá et al., 2014), who recorded values of crude protein below $25.0 \%$.

These results could be attributed to the heterotrophic developmental stage of the bioflocs in the present study, as they required the addition of molasses and hydrated lime, but only at the end of the culture period, whereas Jatobá et al. (2014) used a "mature biofloc", representing the chemoautotrophic stage of development.

In the present study, it was possible to replace $33 \%$ of fishmeal by SPC using a $33 \%$ crude protein diet with $21 \%$ fishmeal. Yang et al. (2015), using diet containing 40\% crude protein and 30\% fishmeal, found a 20\% threshold above which shrimp would be harmed. The difference between our study and that of Yang et al. (2015) may result from biofloc presence in the water, since in BFS, biofloc is used as "natural" food source with some essential nutrients for shrimp, and the protein requirement of Pacific white shrimp, which is influenced by the culture system used (Jatobá et al., 2014).

No change in proximate body composition was observed among dietary treatments (Table 6) which demonstrates that all levels of fishmeal replacement did not interfere in shrimp tissue synthesis (Mente et al., 2002; Carter and Mente, 2014). This could be explained by the similarity among proximate compositions of experimental diets.

To enhance the results obtained in this study or to evaluate higher levels of fishmeal replacement for SPC, new formulations that include ingredients that increase the feed attractiveness are recommended, such as squid meal, krill meal (Sáchez et al., 2012), synthetic amino acids, such as methionine, lysine and/or threonine (Sookying et al., 2013), or taurine, free amino acids, non-essential amino acids, and food stimulants recommended for better growth performance of fish and shrimp (Coman et al., 1996; Martinez et al., 2004). Irrespective of fishmeal replacement level, shrimp in the present study exhibited the same apparent feed efficiency, demonstrating their ability to absorb nutrients from SPC.

\section{Conclusions}

It is viable to partially replace fishmeal by soy protein concentrate in diets for the Pacific white shrimp (L. vannamei) reared in biofloc technology systems.

\section{Acknowledgments}

The authors of this study acknowledge the financial support of the Conselho Nacional de Desenvolvimento Cientifico e Tecnológico (CNPq) in the form of a scholarship offered for the development of the project; Financiadora de Estudos e Projetos (FINEP), for supporting the project "Bases Nutricionais para o Desenvolvimento de Dietas voltadas para o Cultivo do Camarão Litopenaeus vannamei em Regime Intensivo com Flocos Microbianos e Troca Mínima de Água - FINEP/RECARCINA- 2010-2012”; IMCOPA, NICOLUZZI, and GUABI, for financing and providing ingredients for the production of the diets; and the technical support of Karine Goulart de Oliveira, Lucas Gomes Mendes, and Efrayn Wilker de Souza Candia. 
Felipe Vieira, Walter Seiffert, and José Mouriño receive productivity research fellowships from $\mathrm{CNPq}$ (process numbers PQ 309868/2014-9, 302792/2012-0, 308292/ 2014-6, respectively).

\section{References}

Amaya, E. A.; Davis, D. A. and Rouse, D. B. 2007a. Alternative diets for the Pacific white shrimp Litopenaeus vannamei reared under pond conditions. Aquaculture 262:419-425.

Amaya, E. A.; Davis, D. A. and Rouse, D. B. 2007b. Replacement of fish meal in practical diets for the Pacific white shrimp (Litopenaeus vannamei) reared under pond conditions. Aquaculture 262:393-401.

AOAC - Association of Official Analytical Chemists. 2005. Official methods of analyses. 18th ed. Maryland, USA.

APHA - American Public Health Association. 2005. American Water Works Association, Water Pollution Control Association. Standard methods for the examination of water and wastewater. 21st ed. American Public Health Association, Washington, DC, USA.

Avnimelech, Y. 1999. Carbon/nitrogen ratio as a control element in aquaculture systems. Aquaculture 176:227-235.

Avnimelech, Y. 2006. Bio-filters: The need for a new comprehensive approach. Aquacultural Engineering 34:172-178.

Bauer, W.; Prentice-Hernandez, C.; Tesser, M. B.; Wasielesky, J. W. and Poersch, L. H. S. 2012. Substitution of fishmeal with microbial floc meal and soy protein concentrate in diets for the pacific white shrimp Litopenaeus vannamei. Aquaculture 342:112-116.

Burford, M. A.; Thompson, P. J.; McIntosh, R. P.; Bauman, R. H. and Pearson, D. C. 2003. Nutrient and microbial dynamics in highintensity, zero-exchenge shrimp pondes in Belize. Aquaculture 219:393-411.

Carter, C. and Mente, E. 2014. Protein synthesis in crustaceans: a review focused on feeding and nutrition. Open Life Sciences 9:1-10.

Carvalho, R. A.; Ota, R. H.; Kadry, V. O.; Tacon, A. G. and Lemos, D. 2016. Apparent digestibility of protein, energy and amino acids of six protein sources included at three levels in diets for juvenile white shrimp Litopenaeus vannamei reared in high performance conditions. Aquaculture 465:223-234.

Chamberlain, G.; Avnimelech, Y.; McIntoch, R. P. and Velasco, M. 2001. Advantages of aerated microbial reuse systems with balanced C:N II: Composition and nutritional value of organic detritus. Global Aquaculture Advocate 2:22-23.

Coman, G. J.; Sarac, H. Z.; Fielder, D. and Thorne, M. 1996. Evaluation of crystaline amino acids, betaine and AMP as food attractants of the giant tiger prawn (Penaeus monodon). Comparative Biochemistry and Physiology A 113:247-253.

Cuzon, G.; Lawrence, A.; Gaxiola, G.; Rosas, C. and Guillaume, J. 2004. Nutrition of Litopenaeus vannamei reared in tanks or in ponds. Aquaculture 235:513-551.

Drew, M. D.; Borgeson, T. L. and Thiessen, D. L. 2007. A review of processing of feed ingredients to enhance diet digestibility in finfish. Animal Feed Science Technology 138:118-136.

Ebeling, J. M.; Timmons, M. B. and Bisogni, J. J. 2006. Engineering analysis of thestoichiometry of photoautotrophic, autotrophic, and heterotrophic removal of ammonia-nitrogen in aquaculture systems. Aquaculture 257:346-358.

Gamboa-Delgado, J.; Rojas-Casas, M. G.; Nieto-López, M. G. and Cruz-Suárez, L. E. 2013. Simultaneous estimation of the nutritional contribution of fish meal, soy protein isolate and corn gluten to the growth of Pacific white shrimp (Litopenaeus vannamei) using dual stable isotope analysis. Aquaculture 380:33-40.
Gatlin III, D. M.; Barrows, F. T.; Brown, P.; Dabrowski, K.; Gaylord, T. G.; Hardry, R. W.; Herman, E.; Hu, G.; Krogdahl, Â.; Nelson, R.; Overturf, K.; Rust, M.; Sealey, W.; Skonberg, D.; Souza, E. J.; Stone, D.; Wilson, R. and Wurtele, E. 2007. Expanding the utilization of sustainable plant products in aquafeeds: a review. Aquaculture Research 38:551-579.

Hardy, R. W. 2010. Utilization of plant proteins in fish diets: effects of global demand and supplies of fishmeal. Aquaculture Research 41:770-776.

Jatobá, A.; Silva, B. C.; Silva, J. S.; Vieira, F. N.; Mouriño, J. L. P.; Seiffert, W. Q. and Toledo, T. M. 2014. Protein levels for Litopenaeus vannamei in semi-intensive and biofloc systems. Aquaculture 432:365-371.

Kuhn, D. D.; Lawrence, A. L.; Crockett, J. and Taylor, D. 2016. Evaluation of bioflocs derived from confectionary food effluent water as a replacement feed ingredient for fishmeal or soy meal for shrimp. Aquaculture 454:66-71.

Kureshy, N. and Davis, D. A. 2002. Protein requirement for maintenance and maximum weight gain for the Pacific white shrimp, Litopenaeus vannamei. Aquaculture 204:125-143.

Lall, S. P. and Dumas, A. 2015. Nutritional requirements of cultured fish: Formulating nutritionally adequate feeds. p.53-100. In: Feed and feeding practices in aquaculture. Davis, D. A., ed. Woodhead publishing, Cambridge, United Kingdom.

Martinez, J. B.; Chatzifotis, S. and Divanach, P. 2004. Effect of dietary taurine supplementation on growth performance and feed selection of sea bass Dicentrarchus labrax fry fed with demandfeeders. Fisheries Science 70:74-79.

Mente, E.; Coutteau, P.; Houlihan, D.; Davidson, I. and Sorgeloos, P. 2002. Protein turnover, amino acid profile and amino acid flux in juvenile shrimp Litopenaeus vannamei: effects of dietary protein source. Journal of Experimental Biology 205:3107-3122.

Michaud, L.; Blancheton, J. P.; Bruni, V. and Piedrahita, R. 2006. Effect of particulate organic carbon on heterotrophic bacterial populations and nitrification efficiency in biological filters. Aquacultural Engineering 34:224-233.

NRC - National Research Council. 2011. Committee on Nutrient Requirements of Fish and Shrimp. Nutrient requirements of fish and shrimp. NRC National Academic Press, Washington.

Nunes, A. J. P.; Sá, M. V. C.; Andriola-Neto, F. F. and Lemos, D. 2006. Behavioral response to selected feed attractants and stimulants in Pacific white shrimp, Litopenaeus vannamei. Aquaculture 260:244-254.

Paripatananont, T.; Boonyaratpalin, M.; Pengseng, P. and Chotipuntu, P. 2001. Substitution of soy protein concentrate for fishmeal in diets of tiger shrimp Penaeus monodon. Aquaculture Research $32: 369-374$

Ray, A. J.; Lewis, B. L.; Browdy, C. L. and Leffler, J. W. 2010. Suspended solids removal to improve shrimp (Litopenaeus vannamei) production and an evaluation of a plant-based feed in minimal-exchange, superintensive culture systems. Aquaculture 299:89-98.

Sá, M. V. C.; Sabry-Neto, H.; Cordeiro-Júnior, E. and Nunes, A. J. P. 2013. Dietary concentration of marine oil affects replacement of fish meal by soy protein concentrate in practical diets for the white shrimp, Litopenaeus vannamei. Aquaculture Nutrition 19:199-210.

Sabry Neto, H.; Santaella, S. T. and Nunes, A. J. P. 2015. Bioavailability of crude protein and lipid from biofloc meals produced in an activated sludge system for white shrimp, Litopenaeus vannamei. Revista Brasileira de Zootecnia 44:269-275.

Sáchez, R. D.; Fox, J. M.; Gatlin, D. and Lawrence, A. L. 2012. Dietary effect of squid and fish meals on growth and survival of Pacific white shrimp Litopenaeus vannamei in presence or absence of phytoplankton in an indoor tank system. Aquaculture Research 43:1880-1890. 
Schveitzer, R.; Arantes, R. A.; Baloi, M. F.; Costódio, P. F. S.; Arana, L. A.; Seiffert, W. Q. and Andreatta, E. R. 2013a. Use of artificial substrates in the culture of Litopenaeus vannamei (Biofloc System) at different stocking densities: Effects on microbial activity, water quality and production rates. Aquacultural Engineering 54:93-103.

Schveitzer, R.; Arantes, R. A.; Costódio, P. F. S.; Santo, C. M. E.; Arana, L. A.; Seiffert, W. Q. and Andreatta, E. R. 2013b. Effect of different biofloc levels on microbial activity, water quality and performance of Litopenaeus vannamei in a tank system operated with no water Exchange. Aquacultural Engineering 56:59-70.

Scopel, B. R.; Schveitzer, R.; Seiffert, W. Q.; Pierri, V.; Arantes, R. F.; Vieira, F. N. and Vinatea, L.A. 2011. Substituição da farinha de peixe em dietas para camarões marinhos cultivados em sistema bioflocos. Pesquisa Agropecuária Brasileira 46:928-934.

Sookying, D. and Davis, A. 2011. Pond production of Pacific white shrimp (Litopenaeus vannamei) fed high levels of soybean meal in various combinations. Aquaculture 319:141-149.

Sookying, D.; Davis, D. A. and Silva, S. D. 2013. A review of the development and application of soybean-based diets for Pacific white shrimp Litopenaeus vannamei. Aquaculture Nutrition 19:441-448.

Strickland, J. D. H. and Parsons, T. R. 1972. A practical handbook of seawater analysis. vol. 167. Bulletin of Fisheries Research Board, Canada.

Suárez, J. A.; Gaxiola, G.; Mendoza, R.; Cadavid, S.; Garcia, G.; Alanis, G.; Suárez, A.; Faillace, J. and Cuzon, G. 2009. Substitution of fish meal with plant protein sources and energy budget for white shrimp Litopenaeus vannamei (Boone, 1931). Aquaculture 289:118-123.
Tacon, A. G. J.; Cody, J. J.; Conquest, L. D.; Divakaran, S.; Forster, I. P. and Decamp, O. E. 2002. Pacific white shrimp Litopenaeus vannamei (Boone) fed different diets. Aquaculture Nutrition 8:121-131

Tacon, A. G. J. and Metian, M. 2008. Global overview on the use of fish meal and fish oil in industrially compounded aquafeeds: trends and future prospects. Aquaculture 285:146-158.

Taw, N. 2010. Biofloc technology expanding at white shrimp farms biofloc systems deliver high yield with sustainability. Global Aquaculture Advocate 2:20-22.

Wasielesky, J. W.; Atwood, H.; Stokes, A. and Browdy, C. L. 2006. Effect of natural production in a zero exchange suspended microbial floc based super-intensive culture system for white shrimp Litopenaeus vannamei. Aquaculture 258:396-403.

Williams, N. K. C.; Smith, D. M.; Barclay, M. C.; Tabrett, S. J. and Riding, G. 2005. Evidence of a growth factor in some crustacean based feed ingredients in diets for the giant tiger shrimp Penaeus monodon. Aquaculture 250:377-390.

Xie, S. W.; Liu, Y. J.; Zeng, S.; Niu, J. and Tian, L. X. 2016. Partial replacement of fish-meal by soy protein concentrate and soybean meal based protein blend for juvenile Pacific white shrimp, Litopenaeus vannamei. Aquaculture 464:296-302.

Yang, Q.; Tan, B.; Dong, X.; Chi, S. and Liu, H. 2015. Effect of replacing fish meal with extruded soybean meal on growth, feed utilization and apparent nutrient digestibility of juvenile white shrimp (Litopenaeus vannamei). Journal of Ocean University of China 14:865-872.

Zar, J. H. 2010. Biostatistical analysis. 5th ed. Pearson Prentice Hall, Upper Saddle River, NJ. 